\title{
THE ECONOMIC IMPACTS OF REHABILITATION OF SELABAT MUDFLATS NATURE RESERVE, KUCHING, SARAWAK
}

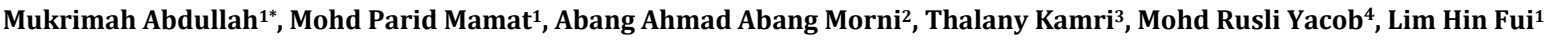 \\ ${ }^{1}$ Forest Research Institute Malaysia (FRIM), 52109 Kepong, Selangor. \\ ${ }^{2}$ Forest Department Sarawak, 93660 Kuching, Sarawak. \\ ${ }^{3}$ Universiti Teknologi MARA Sarawak, 94300 Samarahan, Sarawak. \\ ${ }^{4}$ Universiti Putra Malaysia, 43400 Seri Kembangan, Selangor \\ *Corresponding Author E-mail: mukrimah@frim.gov.my
}

This is an open access article distributed under the Creative Commons Attribution License, which permits unrestricted use, distribution, and reproduction in any medium, provided the original work is properly cited.

\section{ARTICLE DETAILS}

\section{Article History:}

Received 26 June 2018 Accepted 2 July 2018 Available online 1 August 2018

\section{ABSTRACT}

Coastal erosion is a concern to coastline management and it affects the socio-economic well-being of local communities. The rehabilitation of Selabat Mudflats Nature Reserve (SMNR) in Sarawak is one of the most impressive achievements of the "Mangrove and Suitable Tree Species Planting at the National Coastline Program" implemented by the Ministry of Natural Resources and Environment (NRE). The rehabilitation efforts began in 2009, where 20 hectares of Rhizophora mucronata were planted and followed by an additional 1.7 hectares of Casuarina equisetifolia. Previously, this area was a sandy coastline where coastal erosion occurred every year causing local loss of land and properties. However, through conservation and rehabilitation efforts, this area was restored and is now able to generate more income for local communities as well as playing a protective role against coastal erosion caused by coastal waves and strong winds. In 2016, this study was conducted to assess the economic impacts of SMNR rehabilitation. The findings from a sample of 42 households showed that the income generated for local communities around SMNR amounted to RM250, 320 per month or RM3, 003,840 per year. A non-user survey of 401 samples was also conducted, using Contingent Valuation Method to estimate the economic value of SMNR rehabilitation. The result showed the economic value of rehabilitation of SMNR was RM39 million for the year 2016 or RM195, 980 per hectare. These findings showed that the function of rehabilitation and conservation of mangroves forests against coastal erosion brings positive economic impacts. Rehabilitation and conservation of mangrove areas in Malaysia should be given more attention as global warming and rising sea level are going to have negative impacts on coastal settlements. Wise decision-making in the utilisation and allocation of limited resources is important particularly in the context of conflict between conservation and other development that led to its destruction.

\section{KEYWORDS}

Economic value, rehabilitation \& coastal erosion.

\section{INTRODUCTION}

Based on a study, Malaysia has a coastline of 4800 kilometres and has a variety of different characters and ecosystems [1]. The National Coastal Erosion Study in 1985 stated that 30\% of the country's coastline was prone to coastal erosion. Coastal erosion is not only impacting on physical aspects, but also on the economic and societal aspects of the local community. Conservation activities and programs need to be undertaken to address this coastal erosion issue. Pantai Pasir Putih in Kuching Sarawak is one of the conservation projects that have a positive impact on the local community. The area was originally a sandy coastline eroded by waves and strong winds. Locals in Kampung Pasir Putih lost land, property and most of them moved out to nearby village, Kg Selabat. In 2009, under the Mangrove Tree Planting Program and Suitable Species in the National Coastline by the NRE this area is rehabilited. The area was later gazetted as Selabat Mudflats Nature Reserve (SMNR) in 2015, with a total area of 199 hectares. Therefore, a study was conducted to assess the economic impact of rehabilitation of mangrove at SMNR through the application of valuation techniques based on the commodity market and non-market price. This study was also in line with a study that showed how valuation can be used to support ecosystem rehabilitation and protection in coastal and marine habitats [2].

\section{MATERIALS AND METHODS}

Different approaches were used to obtain different types of research data. The approaches are in form of interview, discussion, and survey. There are two types of data collected through this study, namely primary and secondary data. Primary data involves Rapid Rural Appraisal (RRA) and surveys on households / respondents. Secondary data involves collecting information from printed materials such as annual reports, books, journals and other related materials.

\subsection{Socio-economic impacts}

For this study, the approaches applied were Rapid Rural Appraisal (RRA) and survey. According to a researcher, RRA is a tool that enables a quick assessment of the existing environment and the possible impacts of the forest resource utilization and the other environmental services to the local socio-economics livelihood [3]. For survey, it involved households using structured questionnaire (Figure 1). Questionnaire was constructed into few sections covering demographic characteristics of the households, household income sources, and their perception towards the SMNR conservation. A total of 42 households (71\% from total households) from Kampung Pasir Putih and Kampung Selabat were interviewed during the survey, conducted in October 2016. During the household interview, the respondents were briefed on the objectives and purpose of the survey.

Section A: Demographic profile of the household's

Section B: Perception toward the SMNR conservation Section C: Sources of household's income

Figure 1: The structure/organization of questionnaire 


\subsection{Economic benefits}

In Malaysia, very few studies have been conducted to quantify the real economic value and benefits of environmental goods and services. According to research, this could possibly be due to the difficulty in measuring these values as it is not traded in the market place [4]. The Contingent Valuation Method (CVM) is the most commonly used method, in which respondents are directly asked on how much they are willing to pay for conserving the environmental goods and services [5]. Therefore, for the purpose of this study CVM was used to estimate the economic benefits of conserving SMNR. The approach of CVM was the dichotomous choice - double bounded format. The format gives the respondents an opportunity to choose the amount of WTP. There were 5 different bids given to different respondents randomly. The five bids were selected for use: RM2, RM5, RM10, RM15, and RM30. The exploration of whether a person was willing to pay for conservation of SMNR was done using Logistic and Ordinary Least Squares (OLS) models. These models were chosen because of its ability to deal with a dichotomous dependent variable and a well-established theoretical background. The respondents for this study were randomly sampled by Department of Statistics Malaysia. A total 401 respondents were interviewed in 2016.

\section{RESULTS AND DISCUSSION}

\subsection{Socio-economic impacts}

\subsubsection{Impact towards households' income}

A survey was conducted at Kg Pasir Putih and Kg Selabat that used SMNR directly. Local incomes generated from SMNR mangrove areas show its ability to generate income either in form of cash or income in-kind. Cash income refers to income gain from the sales or business related to mangroves products, while income in-kind refers to mangrove resources consumed as food sources by households. In 2016, the average monthly household income was RM3, 404. The income level was higher than the average household income for Rural Malaysia (RM3, 080) and lower than Malaysia (RM6, 141). The result also showed $17 \%$ of the total 225 household members earned income from SMNR mangrove area. Of which, the total income generated from the SMNR mangrove area was RM560 (16\%) per month in 2016, where RM472 was cash income from the mangroves and RM88 was income in-kind (Figure 2). This figure was an increase of $6 \%$ from 2009 to 2016.

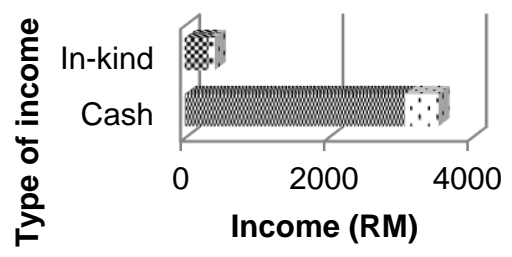

\%otal income

Income from mangrove

Figure 2: Average monthly household income in Kg Pasir Putih and Kg Selabat

\subsubsection{Poverty rate}

The extent of poverty among these local villagers could be seen from the incidence of poverty among the households in the village. Based on a research, poverty in Malaysia is measured on the basis of a minimum expenditure level or the poverty line income (PLI) to separate the poor from non-poor" [6]. In 2014, the per capita PLI for rural Sarawak was RM240. Taking into consideration the rise in the consumers' price index from 111.8 in 2014 to 114.8 in 2016, the per capita PLI was calculated to be RM240 in 2016 and this was used to measure the incidence of poverty in the village studied. For both of these villages, the poverty rate was $4.8 \%$ equivalent to two households below the poverty line. The results of the analysis showed that if no income was derived from SMNR mangrove resources, the poverty rate increased to $9.5 \%$ in 2016.

\subsubsection{Fishery value}

According to a researcher, mangrove ecosystems provide physical factors that are important for the reproduction of many fish and invertebrate species, where it serves as habitat, breeding area. In the SMNR, fisheries are one of local community's sources of income (direct use value) [7]. The marketed value is the amount generated per month by each household from the SMNR. Based on the survey results, estimated the average income from SMNR mangrove areas generated by each household were RM560 per month. By taking into account 447 total number of coastal fishermen adjacent to SMNR, the direct use (fishery) of SMNR was estimated to be RM250, 320 per month or RM3,003,840 per year for 2016.

\subsection{Economic benefits}

\subsubsection{Level of willingness-to-pay (WTP)}

Analysis shows that $77 \%$ of respondents were willing to contribute towards conservation of mangrove forests especially in SMNR through a conservation fund, while another $23 \%$ were not interested in contributing (protest bidder) for SMNR conservation. This latter category they felt that conservation activities should be funded by the government and claimed they could not afford to pay any amount. Table 1 shows the summary of respondents' willingness to pay for conserving SMNR mangrove.

Table 1: Level of Willingness to pay

\begin{tabular}{|ll|}
\hline WTP Level & Percentage \\
\hline RM 1 - RM 5 & 16.6 \\
\hline RM 6 - RM 10 & 28.0 \\
\hline RM 11-RM 15 & 4.2 \\
\hline RM 16-RM 20 & 5.9 \\
\hline RM 21-RM 25 & 0.7 \\
\hline RM 26-RM 30 & 13.7 \\
\hline$>$ RM 30 & 30.9 \\
\hline Total & $\mathbf{1 0 0}$ \\
\hline
\end{tabular}

Frequency analysis shows the level of willingness to pay (WTP) on the conservation of SMNR mangrove area ranging from RM1.00 to RM200 annually. The result also shows that the average WTP was RM29.93 per year. The findings show that the WTP rate of more than RM30 has the highest frequency of $30.9 \%$, followed by the WTP rate of RM6-RM10 by $28 \%$. Meanwhile, the WTP RM1-RM5 has a frequency of $16.6 \%$. However, the minimum WTP level is the WTP level of RM21-RM25, 0.7\% only.

\subsubsection{The CVM analysis}

There are two approaches involved in estimating mean and median WTP, namely the Logistic and the Linear (OLS) analysis (Table 2). The CVM analysis by using Logistic model shows that the Bid price (InitialBid) is negative and significant at the $1 \%$ significance level, which was as expected and in line with the "supply demand curve" theory. The coefficient for income class 3 (INC3) is positive and significant at the $10 \%$ level. From this analysis it implies that the respondents who are in the income class 3 with income of RM3, 501-RM5, 000 influence the respondent's response to the bid. The results also show the variables of respondents that had experience visiting SMNR (EXPvisit) and the price bid presented for the conservation of SMNR is positively correlated, indicating that respondents who visited SMNR are more likely to receive the price bid and it is significant at the level of significance $1 \%$. The $\mathrm{R}^{2}$ value is $0.36,36 \%$ of the variance in the dependent variable is explained by the independent variable. 
Table 2: CVM analysis result

\begin{tabular}{lll|}
\hline Variables & Coefficient & \\
& Logistic Model & OLS Model \\
\hline InitialBID & -0.053 & 0.977 \\
& $(0.012)^{* * *}$ & $(0.076)^{* * *}$ \\
\hline INC3 & 1.780 & 4.399 \\
& $(1.049)^{*}$ & $(3.494)$ \\
INC4 & -0.564 & -4.494 \\
& $(0.547)$ & $(4.328)$ \\
EXPvisit & -0.519 & -4.619 \\
& $(0.444)$ & $(3.064)$ \\
Constant & 3.780 & 12.539 \\
& $(0.484)^{* * *}$ & $(2.285)^{* * *}$ \\
- 2Log likelihood & 153.460 & \\
\hline Number of respondents (n) & 307 & 307 \\
Cox and Snell R & 0.11 & 0.36 \\
R2 & & \\
F Value & & \\
\hline
\end{tabular}

Note: ${ }^{* *},{ }^{* *}, *$ Significance at $1 \%, 5 \%, 10 \%$ level.

\subsubsection{Economic benefits}

In 2016, the estimated value of conservation benefits of SMNR mangrove area calculated based on the individual willingness to pay (WTP) multiplied by the number of households in Kuching District. The annual conservation value or interest for SMNR is based on the calculated WTP mean from logistic and OLS models. There is a difference between mean WTP for different models. In the logistics model, WTP mean values are higher than those given by the OLS model. In 2016, the economic benefits of SMNR conservation based on the willingness to pay (WTP) for the logistics model is about RM39 million, while for OLS model the benefit is about RM12 million. If there is a proposal to charge (i.e. in the form of tax) for the SMNR conservation fund, the maximum amount found in this study is RM84.68 / year, this value may be used by the authorities to determine appropriate conservation fees.

Table 3: Economic benefits of SMNR conservation

\begin{tabular}{|c|c|c|}
\hline \multirow{2}{*}{$\begin{array}{l}\text { Number of } \\
\text { households }\end{array}$} & Logistic Model & OLS Model \\
\hline & WTP=RM84.68 & $W T P=26.11$ \\
\hline 460,935 & RM39, 031, 976 & RM12,035,013 \\
\hline
\end{tabular}

\section{CONCLUSION}

The high amount of economic benefits shows that the rehabilitation and conservation of mangroves to mitigate coastal erosion bring positive effects. The number of households generated from SMNR increase after rehabilitation. Their income from SMNR also rose. In general, the nonusers public is willing to SMNR fund. The conservation of mangroves in Malaysia should thus be given more attention, Economic valuation of environmental goods and services is very important in decision making process will affects the use and allocation of limited resources, in particular in the context of conflict between conservation and development.

\section{ACKNOWLEDGMENT}

This project was funded by JTRD, "Program Penanaman Pokok Bakau dan Spesies bersesuai di Pesisir Pantai Negara" under Ministry of Natural Resources and Environment (NRE). Special thanks go to Forest Research Institute Malaysia (FRIM), Forest Department Sarawak (JHS) and UiTM Samarahan, Kuching Sarawak.

\section{REFERENCES}

[1] Sharifah Mastura, S.A. 1992. The Coastal Zone In Malaysia. Processes, Issues and Management Plan. Bsckground Paper, Malaysian National Conservation Strategy, Economic Planning Unit, Kuala Lumpur.

[2] Spurgeon, J.P.G. 1998. The socio-economic costs and benefits of coastal habitat rehabilitation and creation. Marine Pollution Bulletin, 37 (8-12), 373-382

[3] Liswanti, N., Shantiko, B., Fripp, E., Mwangi, E., Laumonier, Y. 2012. Practical Guide for Socio-economic livelihood, land tenure and rights surveys for Use in Collaborative Ecosystem-based Land Use Planing. CIFOR, Bogor, Indonesia.

[4] Mohd Parid, M., Lim, H.F., Huda Farhana, M.M., Mukrimah, A., Tariq Mubarak, H. 2013. Assessing the Conservation Value of Mangrove Forest Ecosystem. Proceeding of Conference on Forestry and Forest Products Research (CFFPR).

[5] Mukrimah, A., Mohd Parid, M., Lim, H.F., Tariq Mubarak, H. 2015. Economic Analysis of Mangrove Forest: A Case of Delta Kelantan Mangrove Forest (DKMF). The Malaysian Forester, 79 (1,2), 203-211.

[6] Economic Planning Unit Malatsua. 1985. National Coastal Erosion Study, Final Report, Phase 1, Prepared by Stanley Consultant Inc and Others.

[7] Donna J.N. 1999. Trade-offs of Mangrove Area Development in the Philippines. Ecological Economics, 28 (2), 279-298. 